\title{
Minimally Invasive Parathyroidectomy
}

\author{
Lee F. Starker, Annabelle L. Fonseca, Tobias Carling, and Robert Udelsman \\ Department of Surgery, Yale University School of Medicine, P.O. Box 208062, New Haven, CT 06520-8062, USA
}

Correspondence should be addressed to Robert Udelsman, robert.udelsman@yale.edu

Received 1 October 2010; Revised 30 December 2010; Accepted 23 March 2011

Academic Editor: Ajai Kumar Srivastav

Copyright (C 2011 Lee F. Starker et al. This is an open access article distributed under the Creative Commons Attribution License, which permits unrestricted use, distribution, and reproduction in any medium, provided the original work is properly cited.

\begin{abstract}
Minimally invasive parathyroidectomy (MIP) is an operative approach for the treatment of primary hyperparathyroidism (pHPT). Currently, routine use of improved preoperative localization studies, cervical block anesthesia in the conscious patient, and intraoperative parathyroid hormone analyses aid in guiding surgical therapy. MIP requires less surgical dissection causing decreased trauma to tissues, can be performed safely in the ambulatory setting, and is at least as effective as standard cervical exploration. This paper reviews advances in preoperative localization, anesthetic techniques, and intraoperative management of patients undergoing MIP for the treatment of pHPT.
\end{abstract}

\section{Introduction}

Primary hyperparathyroidism (pHPT) is a common endocrine disease caused by a single parathyroid adenoma in $85 \%$ of patients. Identification and resection of the adenoma leads to cure of the disease. Focused unilateral exploration, that is, minimally invasive parathyroidectomy (MIP) of enlarged hyperfunctioning gland(s) under regional anesthetic techniques, has been advocated for the past three decades [1]. Minimally invasive surgery has been defined as the ability of the surgeon to preform traditional surgical procedures employing novel techniques to minimize surgical trauma [2]. In recent years, a number of new minimally invasive techniques have been developed including open minimally invasive parathyroidectomy (MIP) which we describe in this paper. Other minimally invasive approaches, which we will not describe, include video-guided, radio-guided, and endoscopic parathyroidectomies. Prior to current preoperative localization studies, unilateral surgery for pHPT was preformed based upon results of palpation, esophageal imaging, venography, or arteriography $[3,4]$. Unilateral focused cervical exploration was also advocated to reduce the cost and morbidity of surgery while maintaining cure rates [5]. Due to limited exposure obtained during MIP, operative adjuncts are required to confirm the adequacy of resection. The intraoperative parathyroid hormone (IOPTH) assay is now recognized by some experts as the single most useful adjunct in this setting [6]. Current imaging technology has enabled preoperative localization of the hyperfunctioning gland, thus allowing an increasing number of focused unilateral exploration. Sestamibi with single-photon emission computed tomography (SPECT), ultrasonography, and more recently high-quality four-dimensional CT (4DCT) scans identify hyperfunctioning glands in the majority of patients. MIP is now routinely performed at high-volume centers with excellent cure rates and minimal morbidity.

A large number of studies have been published over the last decade describing various techniques in minimally invasive parathyroidectomies, and comparing outcomes to each other and to that of conventional bilateral exploration. Table 1 summarizes these studies.

The indications for MIP are identical to those for traditional bilateral neck exploration, including patients with symptomatic disease and those with asymptomatic pHPT in accordance with recently published guidelines [7]. In addition to those patients with overt symptoms and signs, there is a large number of patients with significant neurocognitive derangements with biochemically proven pHPT that could potentially benefit from resection [8-10].

The current role of MIP in patients with documented or suspected familial pHPT is controversial. In the majority of these patients, conventional bilateral exploration is recommended due to the frequency of multiglandular disease [11]. 
TABLE 1: Summary of studies describing technique and outcomes of minimally invasive parathyroidectomy.

\begin{tabular}{|c|c|c|c|c|c|}
\hline Study & Methods & Study type & Success rate & Pre-op & Intra-op \\
\hline Adil et al. [46] & $\begin{array}{l}305 \text { patients } \\
\text { (1997-2007) }\end{array}$ & $\begin{array}{l}\text { Retrospective case } \\
\text { series }\end{array}$ & $100 \%$ success & Pre-op sestamibi & $\begin{array}{l}\text { IOPTH gamma } \\
\text { probe }\end{array}$ \\
\hline Krausz et al. [47] & 541 patients & $\begin{array}{l}\text { Prospective cohort } \\
\text { study }\end{array}$ & $97 \%$ success & $\begin{array}{l}\text { Pre-op sestamibi scan or } \\
\text { ultrasound }\end{array}$ & IOPTH \\
\hline Sevinç et al. [48] & $\begin{array}{l}56 \text { patients ( } 25 \text { MIP, } 31 \\
\text { MIRP) }\end{array}$ & Prospective study & Similar outcomes & Pre-op sestamibi & $\begin{array}{l}\text { IOPTH in MIP } \\
\text { gamma probe in } \\
\text { MIRP }\end{array}$ \\
\hline Sugino et al. [49] & $\begin{array}{l}167 \text { patients ( } 80 \text { IOPTH } \\
\text { monitoring, } 87 \text { without } \\
\text { IOPTH monitoring) }\end{array}$ & Prospective study & $97 \%$ versus $93 \%$ & $\begin{array}{l}\text { Pre-op sestamibi scan, } \\
\text { ultrasound, or CT scan }\end{array}$ & \\
\hline Fouquet et al. [50] & 200 patients & Prospective study & $\begin{array}{l}72 \% \text { success } 28 \% \\
\text { converted to open }\end{array}$ & $\begin{array}{l}\text { Pre-op sestamibi scan or } \\
\text { ultrasound }\end{array}$ & IOPTH \\
\hline Hessman et al. [51] & $\begin{array}{l}143 \text { patients ( } 75 \text { MIP, } 68 \\
\text { VAP) }\end{array}$ & $\begin{array}{l}\text { Multicenter } \\
\text { prospective } \\
\text { randomized control } \\
\text { trial }\end{array}$ & $\begin{array}{l}\text { Similar outcomes } \\
\text { (conversion rate, } \\
\text { pain), VAP longer }\end{array}$ & Pre-op sestamibi scan & IOPTH \\
\hline Slepavicius et al. [52] & $\begin{array}{l}48 \text { patients ( } 24 \text {-focused } \\
\text { exploration) }\end{array}$ & $\begin{array}{l}\text { Prospective } \\
\text { randomized control } \\
\text { trial }\end{array}$ & Similar outcomes & $\begin{array}{l}\text { Pre-op sestamibi scan or } \\
\text { ultrasound }\end{array}$ & IOPTH \\
\hline Shindo et al. [53] & 186 patients & $\begin{array}{l}\text { Prospective study } \\
\text { (historical cohort) }\end{array}$ & $95 \%$ success & $\begin{array}{l}\text { Pre-op sestamibi scan or } \\
\text { ultrasound }\end{array}$ & IOPTH \\
\hline $\begin{array}{l}\text { Shindo and Rosenthal } \\
\text { [54] }\end{array}$ & 88 patients & Retrospective review & $91 \%$ success & $\begin{array}{l}\text { Pre-op sestamibi scan or } \\
\text { ultrasound }\end{array}$ & IOPTH \\
\hline Rubello et al. [55] & 452 patients 344 MIRP & Prospective study & $93 \%$ success & $\begin{array}{l}\text { Pre-op sestamibi scan or } \\
\text { ultrasound }\end{array}$ & $\begin{array}{l}\text { IOPTH gamma } \\
\text { probe }\end{array}$ \\
\hline Lindekleiv et al. [56] & 47 patients & Retrospective study & $97 \%$ success & Pre-op sestamibi scan & IOPTH \\
\hline Aarum et al. [57] & $\begin{array}{l}50 \text { patients } 23 \text { MIP, } 26 \\
\text { conventional }\end{array}$ & $\begin{array}{l}\text { Prospective } \\
\text { randomized control } \\
\text { trial }\end{array}$ & $96 \%$ versus $94 \%$ & $\begin{array}{l}\text { Pre-op sestamibi and } \\
\text { ultrasound }\end{array}$ & IOPTH \\
\hline Tang et al. [58] & $\begin{array}{l}202 \text { patients } 50 \text { MIP, } 152 \\
\text { open }\end{array}$ & Retrospective study & $\begin{array}{l}\text { Improved quality of } \\
\text { life }\end{array}$ & & \\
\hline Politz et al. [59] & $\begin{array}{l}152 \text { patients ( } 118 \mathrm{MIP} \text {, } \\
34 \text { open) }\end{array}$ & Retrospective study & $98 \%$ success & Pre-op sestamibi scan & $\begin{array}{c}\text { Intra-op gamma } \\
\text { probe }\end{array}$ \\
\hline Pang et al. [60] & 500 patients prospective & Prospective study & $97.4 \%$ success & $\begin{array}{l}\text { Pre-op sestamibi scan }+ \\
\text { ultrasound for incision } \\
\text { placement }\end{array}$ & \\
\hline Soon et al. [61] & 699 patients & Retrospective study & & & $\begin{array}{l}\text { IOPTH (not } \\
\text { used as } \\
\text { management } \\
\text { aid) }\end{array}$ \\
\hline Mihai et al. [62] & $\begin{array}{l}298 \text { patients } \\
182 \text {-sestamibi } 150 \text {-MIP }\end{array}$ & Prospective study & $97.3 \%$ success & Pre-op sestamibi scan & \\
\hline Caudle et al. [63] & 140 patients & Prospective study & $96 \%$ success & Pre-op sestamibi & $\begin{array}{l}\text { Intra-op gamma } \\
\text { probe, frozen } \\
\text { section }\end{array}$ \\
\hline Alfadda et al. [64] & 55 patients & Retrospective study & $93 \%$ success & & \\
\hline Carling et al. [43] & 441 patients & $\begin{array}{l}\text { Prospective case } \\
\text { series }\end{array}$ & $\begin{array}{l}10 \% \text { conversion to } \\
\text { GA (thyroid explo- } \\
\text { ration/conversion to } \\
\text { open } \\
\text { exploration/patient } \\
\text { discomfort) }\end{array}$ & $\begin{array}{l}\text { Pre-op sestamibi scan or } \\
\text { ultrasound }\end{array}$ & IOPTH \\
\hline Barczynski et al. [65] & $\begin{array}{l}60 \text { patients } 30 \text { MIP, } \\
30 \text { VAP }\end{array}$ & $\begin{array}{l}\text { Prospective } \\
\text { randomized control } \\
\text { trial }\end{array}$ & $\begin{array}{l}97 \% \text { success in both } \\
\text { groups, VAP with } \\
\text { decreased pain \& } \\
\text { need for analgesia }\end{array}$ & $\begin{array}{l}\text { Pre-op sestamibi and } \\
\text { ultrasound }\end{array}$ & IOPTH \\
\hline
\end{tabular}


Table 1: Continued.

\begin{tabular}{|c|c|c|c|c|c|}
\hline Study & Methods & Study type & Success rate & Pre-op & Intra-op \\
\hline Cohen et al. [66] & 130 patients & Retrospective review & $98.6 \%$ success & $\begin{array}{l}\text { Pre-op sestamibi scan } \\
\text { and/or ultrasound }\end{array}$ & IOPTH \\
\hline Ollila et al. [67] & 77 patients & Retrospective review & $96 \%$ success & Pre-op sestamibi scan & $\begin{array}{l}\text { Intra-op gamma } \\
\text { probe, selective } \\
\text { frozen section }\end{array}$ \\
\hline Miccoli et al. [68] & $\begin{array}{l}51 \text { patients 26-RA, } \\
\text { 25-GA }\end{array}$ & $\begin{array}{l}\text { Prospective } \\
\text { randomized control } \\
\text { trial }\end{array}$ & $\begin{array}{l}\text { Decreased operative } \\
\text { time and post-op } \\
\text { need for analgesia } \\
\text { with RA }\end{array}$ & $\begin{array}{l}\text { Pre-op sestamibi scan } \\
\text { and ultrasound }\end{array}$ & IOPTH \\
\hline Mekel et al. [69] & $\begin{array}{l}146 \text { patients } 84 \text { MIP } \\
(79 \%)\end{array}$ & Prospective study & & $\begin{array}{l}\text { Pre-op sestamibi scan or } \\
\text { ultrasound }\end{array}$ & IOPTH \\
\hline Grant et al. [70] & 1361 patients & Retrospective review & $\begin{array}{l}54 \% \text { open exploration } \\
44 \% \text { MIP }(2 \% \\
\text { conversion) }\end{array}$ & & \\
\hline Rubello et al. [71] & 268 patients & Retrospective review & $96.8 \%$ success & $\begin{array}{l}\text { Pre-op sestamibi and/or } \\
\text { ultrasound }\end{array}$ & IOPTH \\
\hline Bergenfelz et al. [72] & $\begin{array}{l}50 \text { patients 25-MIVAP, } \\
\text { 25-open }\end{array}$ & $\begin{array}{l}\text { Prospective } \\
\text { randomized control } \\
\text { trial }\end{array}$ & $\begin{array}{l}\text { Decreased operating } \\
\text { time with MIP }\end{array}$ & Pre-op sestamibi scan & IOPTH \\
\hline
\end{tabular}

In the rare cases $(<1 \%)$ of suspicion of parathyroid carcinoma as the etiology of pHPT, a radical resection (i.e., an en bloc resection of the involved hyperfunctioning gland with concomitant ipsilateral thyroid lobectomy) should be undertaken during the initial procedure [12].

\section{Preoperative Imaging}

The development and refinement of parathyroid imaging has been essential for the development of MIP in the treatment of pHPT. Several noninvasive preoperative localization methods are available, including sestamibi-technetium $99^{m}$ scintigraphy, ultrasonography, computed tomography (CT), and magnetic resonance imaging (MRI). The most commonly used modality is sestamibi with SPECT, which generates three-dimensional images [12-15]. Technetium $99^{m}$ methoxyisobutylisonitrile (sestamibi) was initially introduced for cardiac scintigraphy and was incidentally found to be concentrated in parathyroid adenomas [16]. Sestamibi is a monovalent lipophilic cation that diffuses passively through cell membranes and accumulates almost exclusively in mitochondria following negative membrane potentials [17]. Therefore, high mitochondrial density is associated with sestamibi uptake by human parathyroid tissue [18, 19]. The sensitivity of sestamibi scans in the literature is $80 \%[20,21]$. A major limitation of sestamibi scans is due to the coexistence of thyroid nodules, especially Hürthle cell neoplasms or other metabolically active tissues (e.g., lymph nodes and metastatic tumors) that can mimic parathyroid adenomas thereby causing false-positive results. These concomitant abnormalities have been reported to be as high as $40-48 \%$ [22]. A few studies which have evaluated this phenomena saw significant drops in sensitivity of sestamibi scintigraphy when utilized in the presence of a nodular thyroid gland, $96 \%$ versus $81 \%$ [23] and $92 \%$ versus $53 \%$ [24].

Additionally, the parathyroid tumor cell content may be related to sestamibi uptake. Parathyroid oxyphil cell content $>20 \%$ quadruples the rate of obtaining a positive sestamibi scan, while small adenomas $(<600 \mathrm{mg})$ with low $(<20 \%)$ numbers of oxyphil cells are usually associated with a negative scan [25]. Additionally, sestamibi with SPECT does not provide detailed anatomical depiction and can only rarely detect double adenomas and multiglandular hyperplasia [26].

Ultrasound (US) is effective, noninvasive, and inexpensive, but its limitations include both operator dependency and being limited to application in the neck because it cannot image mediastinal tumors. The normal parathyroid gland is generally too small to be visualized sonographically, whereas the parathyroid enlargement seen in pHPT is often identified as a homogeneously hypoechoic extrathyroidal ovoid mass. The accuracy of lateralization and correct quadrant localization of parathyroid tumors is highly variable, especially for ultrasound, due to operatordependence. Similar to sestamibi with SPECT, the ability of an ultrasound to detect the parathyroid abnormality is reduced in milder forms of pHPT (i.e., only mildly elevated PTH and calcium levels) and in obese patients [27]. Thus, some surgeons suggest reserving sestamibi with SPECT for patients with negative US or as an adjunct to patients with concomitant thyroid disease $[28,29]$. Additionally, some studies suggest improved sensitivity of parathyroid tumor localization using sestamibi with SPECT and surgeon-performed US [30].

Four-dimensional CT scan (4DCT) is a promising new parathyroid imaging technique. 4DCT scan is similar to CT angiography. The term is derived from three-dimensional CT scanning with the additional dimension referring to 


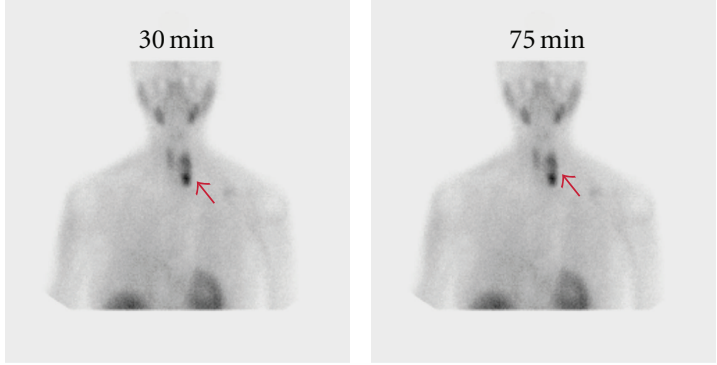

(a)

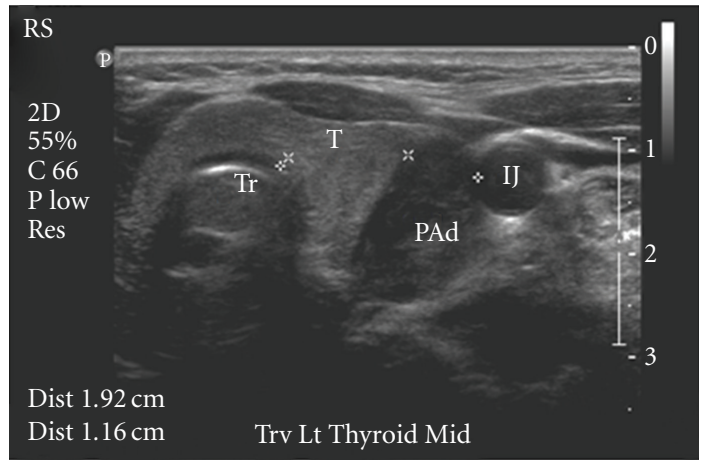

(b)

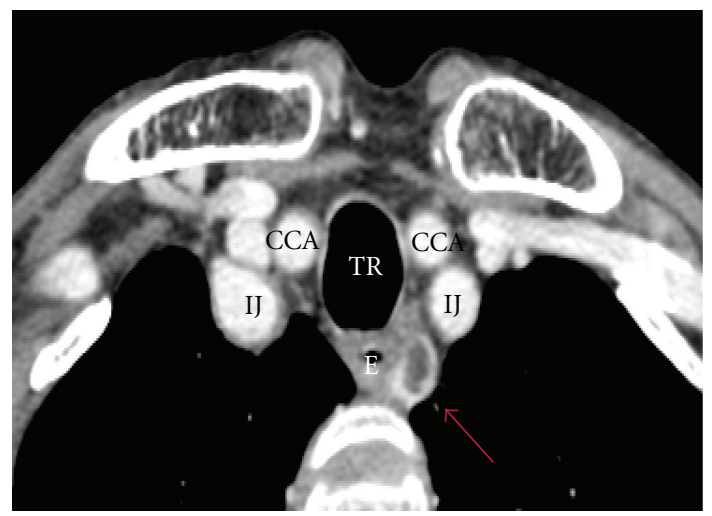

(c)

FIGURE 1: Preoperative imaging in primary hyperparathyroidism. (a) Sestamibi with SPECT displaying focal retention in the left lower position (arrow) after 30 and 75 minutes washout, respectively. (b) Corresponding cervical ultrasound from the same patient showing a large hypoechoic cystic parathyroid adenoma (arrow). The left thyroid lobe (T), trachea (Tr), and left internal jugular vein (IJ) are indicated. (c) Four-dimensional parathyroid CT scan depicting an ectopically positioned left superior paraesophageal parathyroid adenoma (arrow). IJ: internal jugular vein; T: trachea; E: esophagus; CCA: common carotid artery.

the changes in perfusion of contrast over time. Exquisitely detailed multiplanar images are obtained to accentuate the differences in the perfusion characteristics of hyperfunctioning parathyroid glands (i.e., rapid uptake and washout), compared with normal parathyroid glands and other structures in the neck (Figure 1). The images provide both anatomic and functional information (based on changes in perfusion) in a single study that the operating surgeon can easily interpret. To date, parathyroid 4DCT has mainly been used as an adjunct to other imaging modalities in the remedial setting [31]. In a study by Rodgers et al., 4DCT displayed improved sensitivity (88\%) over sestamibi imaging (65\%) and ultrasonography (57\%), when these imaging studies were used to lateralize hyperfunctioning parathyroid glands to one side of the neck. Moreover, when used to localize parathyroid tumors to the correct quadrant of the neck (i.e., right inferior, right superior, left inferior, or left superior), the sensitivity of 4D-CT (70\%) was significantly higher than sestamibi imaging (33\%) and ultrasonography (29\%) [31].

Even in patients with negative, discordant, or unconvincing preoperative imaging studies, the cure rates are excellent in experienced hands; however, invasive localization procedures such as selective parathyroid venous sampling (SVS) with measurements of PTH may be indicated. Rapid PTH measurements have been successfully employed in the angiography suite, and interventional radiologists can obtain additional samples from a region in which a subtle but potentially significant PTH gradient is detected [32]. Ultrasonography can be employed to guide preoperative aspiration of a putative parathyroid gland in which PTH is measured to confirm that the suspected tissue is parathyroid. This technique, like venous localization, should be reserved for remedial cases [33].

\section{Anesthesia}

The majority of parathyroid explorations are performed under general anesthesia utilizing either a standard general endotracheal tube (ETT) or a laryngeal mask airway (LAM). Conversely, high-volume centers have utilized monitored anesthesia care (MAC) with local and regional anesthesia. The regional block can be performed by the surgeon, just prior to incision after mild intravenous sedation has been administered (Figure 2). We use 1\% lidocaine containing 1:100000 epinephrine employing a total of $20 \mathrm{~mL}$. Intravascular infiltration of local analgesic agents must be avoided. Unilateral infiltration posteriorly at Erb's point (located on the posterior border of the sternocleidomastoid muscle midway between its attachments to the mastoid process, the sternum, and the clavicle) and along the anterior border of the sternocleidomastoid muscle on the side of the localized gland and along the area of incision provides excellent analgesia during virtually every case. Intravenous sedation is maintained to alleviate patient anxiety while maintaining a patient who is capable of phonating.

Regional anesthesia for the resection of hyperfunctioning parathyroid glands avoids potential complications associated with general anesthesia, which includes endotracheal intubation, which has been associated with up to a 5\% risk of vocal cord changes and damage [35]. Furthermore, with patients remaining conscious during exploration, the operating surgeon may assess functional status of phonation. Conversion to general anesthesia is occasionally performed and may be due to concomitant thyroid pathology, concern for parathyroid carcinoma, persistently elevated intraoperative PTH levels, difficulty in ensuring the safety of the recurrent laryngeal nerve, and patient discomfort [3]. Regardless of the reason for conversion in all cases, conversion should be 


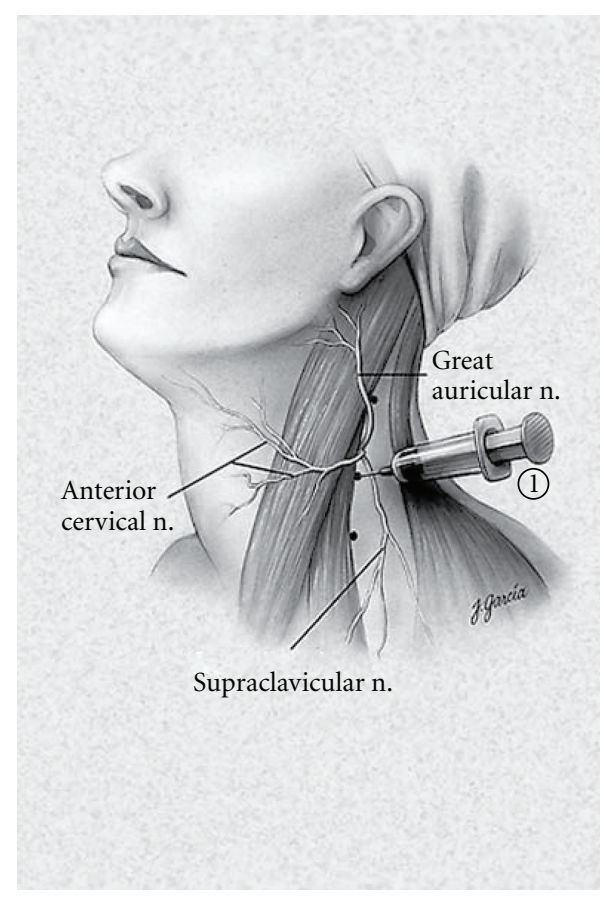

(a)

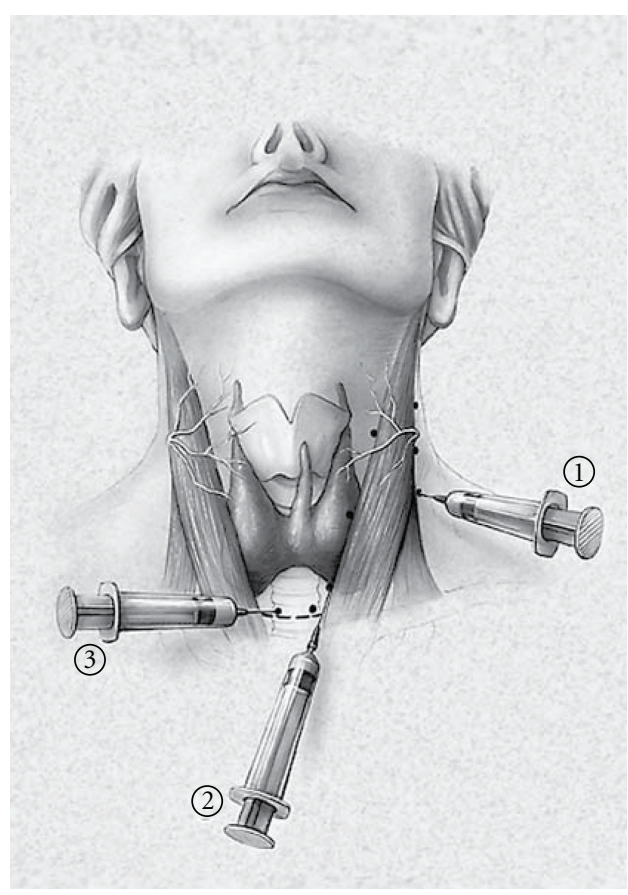

(b)

FIGURE 2: Cervical block anesthesia. (a) A superficial cervical block is administered posterior and deep to the sternocleidomastoid muscle (SCM; 1). (b) Local infiltration is also performed along the anterior border of the SCM [2], followed by a local field block [3]. (From [34], with permission, Copyright 2002, Lippincott Williams \&Wilkins).

done in a controlled fashion with protection of the surgical field [3]. We recently reported a $10.6 \%$ conversion to general anesthesia in a study of 441 consecutive patients [25].

\section{Procedure}

A 20-gauge intravenous catheter is placed in the antecubital fossa, and a single baseline PTH level is obtained in the preoperative holding area. The patient is transported to the operating room and placed in the semifowler position, and a screen is used to protect the patient's face from the operative field. The anesthesia personal will require access to the intravenous line to obtain PTH measurements (Figure 3) [34]. Moderate sedation is administered, and a regional cervical nerve block is then administered as described. An abbreviated Kocher incision (approximately $3 \mathrm{~cm}$ ) is then made, and the anterior compartment of the neck entered the median raphe is mobilized, the parathyroid adenoma visualized, the recurrent laryngeal nerve is protected, and the adenoma is excised.

Once resection is complete, serial blood draws are obtained. Adequacy of resection is confirmed when the patient's preoperative baseline PTH level decreases by at least $50 \%$ and returns to the normal range [36-40].

\section{Intraoperative Parathyroid Hormone Monitoring}

In 1990, intraoperative PTH monitoring was introduced and allowed for a biochemical alternative to direct fourgland visualization [41]. Prior to this, multiglandular disease

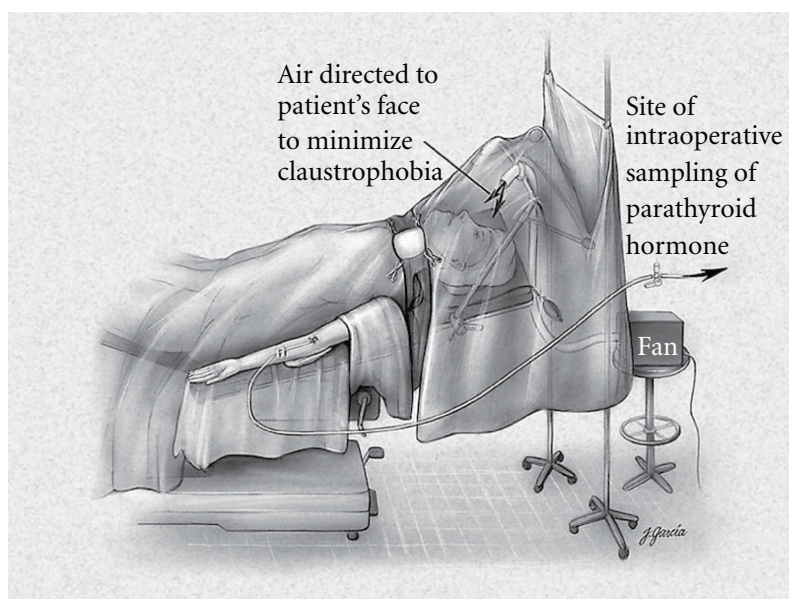

FIgURE 3: The patient has a large-bore peripheral intravenous line inserted, which is used for medication and fluid administration, as well as sampling for parathyroid hormone (PTH) levels. The patient is awake, and a fan is used to blow room air gently toward his or her face to minimize the sensation of claustrophobia. (From [36], with permission, Copyright 2002, Lippincott Williams \& Wilkins).

could not be accurately ruled out without directly visualizing at least all four glands. Intraoperative PTH monitoring is feasible because PTH has a short half-life of the hormone (3-5 minutes). In some patients, the PTH level fails to decline after resection, thus indicating residual abnormal parathyroid tissue, and further exploration is required. 
Since the most advantageous time to cure pHPT is during the first surgical exploration, it is the obligation of the surgeon to perform a meticulous exploration, evaluating both eutopic and ectopic sites. This exploration may include the retroesophageal space, thymus gland, carotid sheaths, and submandibular region for undescended glands. If the occult gland is still not identified, additional intraoperative adjuncts may be used, including ultrasound and bilateral internal jugular vein sampling to determine if an ipsilateral PTH gradient is present. This technique has guided us to explore upstream and locate occult undescended or partially descended glands. Partial or complete thyroid lobectomy for intrathyroidal parathyroid tumors can be performed depending on the suspected location of the missing gland. In the case of difficult localization of the hyperfunctioning gland, a traditional bilateral exploration may need to be performed. In the rare case where a mediastinal gland is suspected after bilateral exploration has not revealed the hyperfunctioning gland, a partial sternotomy may rarely be required during initial exploration [42].

\section{Complications}

The complications that may be associated with MIP are the same as complications that may be associated with conventional bilateral exploration, and the complication rates are at least as low as those associated with the latter. However, due to the use of regional anesthesia, MIP avoids potential complications associated with general anesthesia, which includes endotracheal intubation, which has been associated with the risk of vocal cord changes and damage. Hematomas and ipsilateral recurrent laryngeal nerve injury may occur with MIP. Temporary hypocalcemia (due to hungry bone syndrome) may also occur. In a prospectively collected and retrospectively reviewed series of 656 consecutive parathyroidectomies performed between 1990 and 2001 (of which 401 were performed in the conventional fashion, and 255 were performed as MIP), we reported no significant difference in complication rates (3\% and $1.2 \%$, resp.) or cure rates $(97 \%$ and $99 \%$, resp.) [43].

\section{Patients with Recurrent or Persistent Disease}

Despite modern preoperative imaging techniques, endocrine surgeons are still faced with three distinct groups of patients who present unique and challenging management issues: (1) those with persistent pHPT, (2) or recurrent, and lastly (3) those who have had prior neck surgery, particularly thyroid resections, and develop pHPT. Other situations of difficult neck dissections arise in the setting of parathyroid carcinoma and parathyromatosis due either to carcinoma or spillage during a previous adenoma resection and those patients who have had radiation to the neck and/or mediastinum. Regardless of the pathophysiology, the challenge is the same as remedial surgery in previously violated surgical planes. Reoperative cervical and mediastinal exploration is associated with an overall increase of failure and complication rates $[44,45]$.

\section{Conclusions}

Due to the significant advancements in technology, MIP has become the procedure of choice for sporadic pHPT at specialized centers. Minimally invasive parathyroidectomy has improved cosmetic results due to smaller incisions, decreased surgical trauma leading to less postoperative pain, shorter operative times, and a decreased overall hospital stay. The rate of cure was recently shown to be comparable or improved compared to traditional bilateral neck explorations and can be performed in the outpatient setting. It is to be emphasized that MIP and conventional cervical exploration are both highly successful and associated with low complication rates. Surgeon experience, regardless of the technique employed, is paramount to obtain excellent results.

\section{References}

[1] S. I. Roth, C. Wang, and J. T. Potts Jr., "The team approach to primary hyperparathyroidism," Human Pathology, vol. 6, no. 6, pp. 645-648, 1975.

[2] J. G. Hunter, "Minimally invasive surgery: the next frontier," World Journal of Surgery, vol. 23, no. 4, pp. 422-424, 1999.

[3] T. Carling and R. Udelsman, "Focused approach to parathyroidectomy," World Journal of Surgery, vol. 32, no. 7, pp. 15121517, 2008.

[4] S. Tibblin, A. G. Bondeson, and O. Ljungberg, "Unilateral parathyroidectomy in hyperparathyroidism due to single adenoma," Annals of Surgery, vol. 195, no. 3, pp. 245-252, 1982.

[5] C. A. Wang, "Surgical management of primary hyperparathyroidism," Current Problems in Surgery, vol. 22, no. 11, pp. 1-50, 1985.

[6] H. Chen, L. J. Sokoll, and R. Udelsman, “Outpatient minimally invasive parathyroidectomy: a combination of sestamibiSPECT localization, cervical block anesthesia, and intraoperative parathyroid hormone assay," Surgery, vol. 126, no. 6, pp. 1016-1022, 1999.

[7] J. P. Bilezikian, A. A. Khan, and J. T. Potts Jr., "Guidelines for the management of asymptomatic primary hyperparathyroidism: summary statement from the third international workshop," Journal of Clinical Endocrinology and Metabolism, vol. 94, no. 2, pp. 335-339, 2009.

[8] J. Rastad, C. Joborn, G. Akerström, and S. Ljunghall, "Incidence, type and severity of psychic symptoms in patients with sporadic primary hyperparathyroidism," Journal of Endocrinological Investigation, vol. 15, no. 9, supplement 6, pp. 149-156, 1992.

[9] S. J. Silverberg, "Non-classical target organs in primary hyperparathyroidism," Journal of Bone and Mineral Research, vol. 17, no. 2, pp. N117-N125, 2002.

[10] S. A. Roman, J. A. Sosa, L. Mayes et al., "Parathyroidectomy improves neurocognitive deficits in patients with primary hyperparathyroidism," Surgery, vol. 138, no. 6, pp. 1121-1129, 2005.

[11] T. Carling, "Multiple endocrine neoplasia syndrome: genetic basis for clinical management," Current Opinion in Oncology, vol. 17, no. 1, pp. 7-12, 2005.

[12] T. Carling and R. Udelsman, "Parathyroid tumors," Current Treatment Options in Oncology, vol. 4, no. 4, pp. 319-328, 2003.

[13] W. C. Lavely, S. Goetze, K. P. Friedman et al., "Comparison of SPECT/CT, SPECT, and planar imaging with single- and 
dual-phase ${ }^{99 \mathrm{~m}}$ Tc-sestamibi parathyroid scintigraphy," Journal of Nuclear Medicine, vol. 48, no. 7, pp. 1084-1089, 2007.

[14] B. Harris, D. Bailey, P. Roach, D. Marshman, A. McElduff, and G. King, "Use of fusion imaging to localize an ectopic thoracic parathyroid adenoma," Annals of Thoracic Surgery, vol. 82, no. 2, pp. 719-721, 2006.

[15] R. Mihai, D. Simon, and P. Hellman, "Imaging for primary hyperparathyroidism-an evidence-based analysis," Langenbeck's Archives of Surgery, vol. 394, no. 5, pp. 765-784, 2009.

[16] A. J. Coakley, A. G. Kettle, C. P. Wells, M. J. O’Doherty, and R. E. C. Collins, "99Tcm sestamibi: a new agent for parathyroid imaging," Nuclear Medicine Communications, vol. 10, no. 11, pp. 791-794, 1989.

[17] A. S. Arbab, K. Koizumi, K. Toyama, T. Arai, and T. Araki, "Technetium-99m-tetrofosmin, technetium-99m-MIBI and thallium-201 uptake in rat myocardial cells," Journal of Nuclear Medicine, vol. 39, no. 2, pp. 266-271, 1998.

[18] M. J. O’Doherty, A. G. Kettle, P. Wells, R. E. C. Collins, and A. J. Coakley, "Parathyroid imaging with technetium-99msestamibi: preoperative localization and tissue uptake studies," Journal of Nuclear Medicine, vol. 33, no. 3, pp. 313-318, 1992.

[19] N. Hetrakul, A. C. Civelek, C. A. Stagg, and R. Udelsman, "In vitro accumulation of technetium-99m-sestamibi in human parathyroid mitochondria," Surgery, vol. 130, no. 6, pp. 10111018, 2001.

[20] Y. Chapuis, Y. Fulla, P. Bonnichon et al., "Values of ultrasonography, sestamibi scintigraphy, and intraoperative measurement of 1-84 PTH for unilateral neck exploration of primary hyperparathyroidism," World Journal of Surgery, vol. 20, no. 7, pp. 835-840, 1996.

[21] C. Arici, W. K. Cheah, P. H. G. Ituarte et al., "Can localization studies be used to direct focused parathyroid operations?" Surgery, vol. 129, no. 6, pp. 720-729, 2001.

[22] A. C. Civelek, E. Ozalp, P. Donovan, and R. Udelsman, "Prospective evaluation of delayed technetium-99m sestamibi SPECT scintigraphy for preoperative localization of primary hyperparathyroidism," Surgery, vol. 131, no. 2, pp. 149-157, 2002.

[23] Y. Erbil, U. Barbaros, B. T. Yanik et al., "Impact of gland morphology and concomitant thyroid nodules on preoperative localization of parathyroid adenomas," Laryngoscope, vol. 116, no. 4, pp. 580-585, 2006.

[24] A. Sukan, M. Reyhan, M. Aydin et al., "Preoperative evaluation of hyperparathyroidism: the role of dual-phase parathyroid scintigraphy and ultrasound imaging," Annals of Nuclear Medicine, vol. 22, no. 2, pp. 123-131, 2008.

[25] Y. Erbil, U. Barbaros, M. Tükenmez et al., "Impact of adenoma weight and ectopic location of parathyroid adenoma on localization study results," World Journal of Surgery, vol. 32, no. 4, pp. 566-571, 2008.

[26] A. G. Kettle and M. J. O’Doherty, "Parathyroid imaging: how good is it and how should it be done?" Seminars in Nuclear Medicine, vol. 36, no. 3, pp. 206-211, 2006.

[27] E. Berber, R. T. Parikh, N. Ballem, C. N. Garner, M. Milas, and A. E. Siperstein, "Factors contributing to negative parathyroid localization: an analysis of 1000 patients," Surgery, vol. 144, no. 1, pp. 74-79, 2008.

[28] M. Kebapci, E. Entok, N. Kebapci, and B. Adapinar, "Preoperative evaluation of parathyroid lesions in patients with concomitant thyroid disease: role of high resolution ultrasonography and dual phase technetium 99m sestamibi scintigraphy," Journal of Endocrinological Investigation, vol. 27, no. 1, pp. 2430, 2004.
[29] H. Gilat, M. Cohen, R. Feinmesser et al., "Minimally invasive procedure for resection of a parathyroid adenoma: the role of preoperative high-resolution ultrasonography," Journal of Clinical Ultrasound, vol. 33, no. 6, pp. 283-287, 2005.

[30] G. B. Melton, H. Somervell, K. P. Friedman, M. A. Zeiger, and A. C. Civelek, "Interpretation of ${ }^{99 \mathrm{~m}} \mathrm{Tc}$ sestamibi parathyroid SPECT scan is improved when read by the surgeon and nuclear medicine physician together," Nuclear Medicine Communications, vol. 26, no. 7, pp. 633-638, 2005.

[31] S. E. Rodgers, G. J. Hunter, L. M. Hamberg et al., "Improved preoperative planning for directed parathyroidectomy with 4dimensional computed tomography," Surgery, vol. 140, no. 6 , pp. 932-941, 2006.

[32] R. Udelsman, J. E. Aruny, P. I. Donovan et al., "Rapid parathyroid hormone analysis during venous localization," Annals of Surgery, vol. 237, no. 5, pp. 714-721, 2003.

[33] N. D. Perrier, P. Ituarte, S. Kikuchi et al., "Intraoperative parathyroid aspiration and parathyroid hormone assay as an alternative to frozen section for tissue identification," World Journal of Surgery, vol. 24, no. 11, pp. 1319-1322, 2000.

[34] R. Udelsman, "Unilateral neck exploration under local or regional anesthesia," in Minimally Invasive Endocrine Surgery, M. Gagner, Ed., Lippincott Williams \& Wilkins, Philadelphia, $\mathrm{Pa}, \mathrm{USA}, 2002$.

[35] A. Stojadinovic, A. R. Shaha, R. F. Orlikoff et al., "Prospective functional voice assessment in patients undergoing thyroid surgery," Annals of Surgery, vol. 236, no. 6, pp. 823-832, 2002.

[36] R. Udelsman, "Six hundred fifty-six consecutive explorations for primary hyperparathyroidism," Annals of Surgery, vol. 235, no. 5, pp. 665-672, 2002.

[37] H. Chen, Z. Pruhs, J. R. Starling, and E. Mack, "Intraoperative parathyroid hormone testing improves cure rates in patients undergoing minimally invasive parathyroidectomy," Surgery, vol. 138, no. 4, pp. 583-590, 2005.

[38] G. L. Irvin III, D. L. Prudhomme, G. T. Deriso, G. Sfakianakis, and S. K. C. Chandarlapaty, "A new approach to parathyroidectomy," Annals of Surgery, vol. 219, no. 5, pp. 574-581, 1994.

[39] G. L. Irvin III, G. Sfakianakis, L. Yeung et al., "Ambulatory parathyroidectomy for primary hyperparathyroidism," Archives of Surgery, vol. 131, no. 10, pp. 1074-1078, 1996.

[40] D. L. Fraker, H. Harsono, and R. Lewis, "Minimally invasive parathyroidectomy: benefits and requirements of localization, diagnosis, and intraoperative PTH monitoring. long-term results," World Journal of Surgery, vol. 33, no. 11, pp. 22562265, 2009.

[41] G. L. Irvin III, "American Association of Endocrine Surgeons. Presidential address: chasin' hormones," Surgery, vol. 126, no. 6, pp. 993-997, 1999.

[42] J. S. Gold, P. I. Donovan, and R. Udelsman, "Partial median sternotomy: an attractive approach to mediastinal parathyroid disease," World Journal of Surgery, vol. 30, no. 7, pp. 12341239, 2006.

[43] T. Carling, P. Donovan, C. Rinder, and R. Udelsman, "Minimally invasive parathyroidectomy using cervical block: reasons for conversion to general anesthesia," Archives of Surgery, vol. 141, no. 4, pp. 401-404, 2006.

[44] R. Udelsman and P. I. Donovan, "Remedial parathyroid surgery: changing trends in 130 consecutive cases," Annals of Surgery, vol. 244, no. 3, pp. 471-477, 2006.

[45] J. D. Prescott and R. Udelsman, "Remedial operation for primary hyperparathyroidism," World Journal of Surgery, vol. 33, no. 11, pp. 2324-2334, 2009. 
[46] E. Adil, T. Adil, F. Fedok, G. Kauffman, and D. Goldenberg, "Minimally invasive radioguided parathyroidectomy performed for primary hyperparathyroidism," OtolaryngologyHead and Neck Surgery, vol. 141, no. 1, pp. 34-38, 2009.

[47] M. M. Krausz, S. Ish-Shalom, and A. Ofer, "Minimally invasive parathyroidectomy for treatment of primary hyperparathyroidism caused by parathyroid adenoma," Harefuah, vol. 149, no. 6, pp. 353-356, 404, 2010.

[48] A. I. Sevinç, Z. S. Derici, R. Bekiš et al., "Success of minimally invasive single-gland exploration using the quick intraoperative parathyroid assay," Acta Chirurgica Belgica, vol. 110, no. 4, pp. 463-466, 2010.

[49] K. Sugino, K. Ito, M. Nagahama et al., "Minimally invasive surgery for primary hyperparathyroidism with or without intraoperative parathyroid hormone monitoring," Endocrine Journal, vol. 57, no. 11, pp. 953-958, 2010.

[50] T. Fouquet, A. Germain, R. Zarnegar et al., "Totally endoscopic lateral parathyroidectomy: prospective evaluation of 200 patients," Langenbeck's Archives of Surgery, vol. 395, no. 7, pp. 935-940, 2010.

[51] O. Hessman, J. Westerdahl, N. Al-Suliman, P. Christiansen, P. Hellman, and A. Bergenfelz, "Randomized clinical trial comparing open with video-assisted minimally invasive parathyroid surgery for primary hyperparathyroidism," British Journal of Surgery, vol. 97, no. 2, pp. 177-184, 2010.

[52] A. Slepavicius, V. Beisa, V. Janusonis, and K. Strupas, "Focused versus conventional parathyroidectomy for primary hyperparathyroidism: a prospective, randomized, blinded trial," Langenbeck's Archives of Surgery, vol. 393, no. 5, pp. 659-666, 2008.

[53] M. L. Shindo, J. M. Rosenthal, and T. Lee, "Minimally invasive parathyroidectomy using local anesthesia with intravenous sedation and targeted approaches," Otolaryngology — Head and Neck Surgery, vol. 138, no. 3, pp. 381-387, 2008.

[54] M. L. Shindo and J. M. Rosenthal, "Minimal access parathyroidectomy using the focused lateral approach: technique, indication, and results," Archives of Otolaryngology —Head and Neck Surgery, vol. 133, no. 12, pp. 1227-1234, 2007.

[55] D. Rubello, G. Mariani, and M. R. Pelizzo, "Minimally invasive radio-guided parathyroidectomy on a group of 452 primary hyperparathyroid patients: refinement of preoperative imaging and intraoperative procedure," NuklearMedizin, vol. 46, no. 3, pp. 85-92, 2007.

[56] H. Lindekleiv, J. Due, L. Thuy, T. A. Hansen, and P. Nilsen, "Minimally invasive treatment of primary hyperparathyroidism," Tidsskrift for den Norske Laegeforening, vol. 127, no. 9, pp. 1204-1206, 2007.

[57] S. Aarum, J. Nordenström, E. Reihnér et al., "Operation for primary hyperparathyroidism: the new versus the old order: a randomised controlled trial of preoperative localisation," Scandinavian Journal of Surgery, vol. 96, no. 1, pp. 26-30, 2007.

[58] T. Tang, S. Dolan, B. Robinson, and L. Delbridge, "Does the surgical approach affect quality of life outcomes? A comparison of minimally invasive parathyroidectomy with open parathyroidectomy," International Journal of Surgery, vol. 5, no. 1, pp. 17-22, 2007.

[59] D. Politz, C. D. Livingston, B. Victor, R. Askew, and L. Jones, "Minimally invasive radio-guided parathyroidectomy in 152 consecutive patients with primary hyperparathyroidism," Endocrine Practice, vol. 12, no. 6, pp. 630-634, 2006.

[60] T. Pang, P. Stalberg, S. Sidhu et al., "Minimally invasive parathyroidectomy using the lateral focused mini-incision technique without intraoperative parathyroid hormone monitoring," British Journal of Surgery, vol. 94, no. 3, pp. 315-319, 2007.

[61] P. S. H. Soon, M. W. Yeh, M. S. Sywak, P. Roach, L. W. Delbridge, and S. B. Sidhu, "Minimally invasive parathyroidectomy using the lateral focused miniincision approach: is there a learning curve for surgeons experienced in the open procedure?" Journal of the American College of Surgeons, vol. 204, no. 1, pp. 91-95, 2007.

[62] R. Mihai, F. F. Palazzo, F. V. Gleeson, and G. P. Sadler, "Minimally invasive parathyroidectomy without intraoperative parathyroid hormone monitoring in patients with primary hyperparathyroidism," British Journal of Surgery, vol. 94, no. 1, pp. 42-47, 2007.

[63] A. S. Caudle, S. E. Brier, B. F. Calvo, J. K. Hong, M. O. Meyers, and D. W. Ollila, "Experienced radio-guided surgery teams can successfully perform minimally invasive radioguided parathyroidectomy without intraoperative parathyroid hormone assays," American Surgeon, vol. 72, no. 9, pp. 785789, 2006.

[64] A. Alfadda, A. Hagr, K. Al-Qahtani, and R. Tabah, "Radioguided minimally invasive parathyroidectomy under local anesthesia," West African Journal of Medicine, vol. 25, no. 2, pp. 134-137, 2006.

[65] M. Barczyński, S. Cichoń, A. Konturek, and W. Cichoń, "Minimally invasive video-assisted parathyroidectomy versus open minimally invasive parathyroidectomy for a solitary parathyroid adenoma: a prospective, randomized, blinded trial," World Journal of Surgery, vol. 30, no. 5, pp. 721-731, 2006.

[66] M. S. Cohen, S. E. Finkelstein, L. M. Brunt et al., "Outpatient minimally invasive parathyroidectomy using local/regional anesthesia: a safe and effective operative approach for selected patients," Surgery, vol. 138, no. 4, pp. 681-689, 2005.

[67] D. W. Ollila, A. S. Caudle, W. G. Cance et al., "Successful minimally invasive parathyroidectomy for primary hyperparathyroidism without using intraoperative parathyroid hormone assays," American Journal of Surgery, vol. 191, no. 1, pp. 52 56, 2006.

[68] P. Miccoli, L. Barellini, J. M. Monchik, R. Rago, and P. F. Berti, "Randomized clinical trial comparing regional and general anaesthesia in minimally invasive video-assisted parathyroidectomy," British Journal of Surgery, vol. 92, no. 7, pp. 814818, 2005.

[69] M. Mekel, A. Mahajna, S. Ish-Shalom et al., "Minimally invasive surgery for the treatment of hyperparathyroidism," Israel Medical Association Journal, vol. 7, no. 5, pp. 323-327, 2005.

[70] C. S. Grant, G. Thompson, D. Farley et al., "Primary hyperparathyroidism surgical management since the introduction of minimally invasive parathyroidectorny: Mayo clinic experience," Archives of Surgery, vol. 140, no. 5, pp. 472-479, 2005.

[71] D. Rubello, M. R. Pelizzo, G. Boni et al., "Radioguided surgery of primary hyperparathyroidism using the lowdose ${ }^{99 \mathrm{~m}}$ Tc-sestamibi protocol: multiinstitutional experience from the Italian Study Group on Radioguided Surgery and Immunoscintigraphy (GISCRIS)," Journal of Nuclear Medicine, vol. 46, no. 2, pp. 220-226, 2005.

[72] A. Bergenfelz, V. Kamigiesser, A. Zielke, C. Nies, and M. Rothmund, "Conventional bilateral cervical exploration versus open minimally invasive parathyroidectomy under local anaesthesia for primary hyperparathyroidism," British Journal of Surgery, vol. 92, no. 2, pp. 190-197, 2005. 


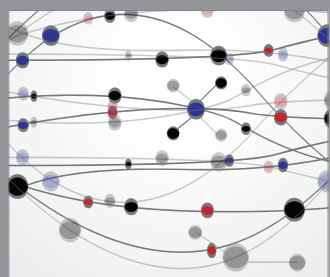

The Scientific World Journal
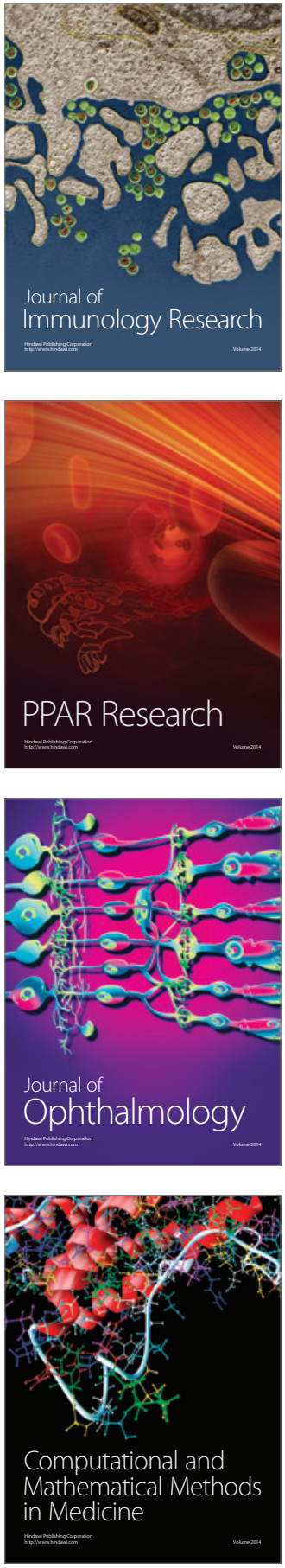

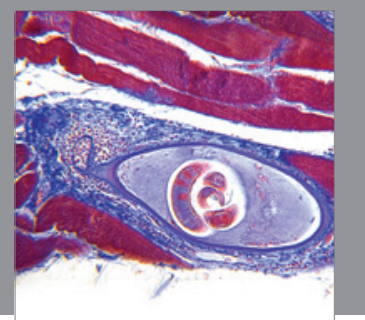

Gastroenterology

Research and Practice
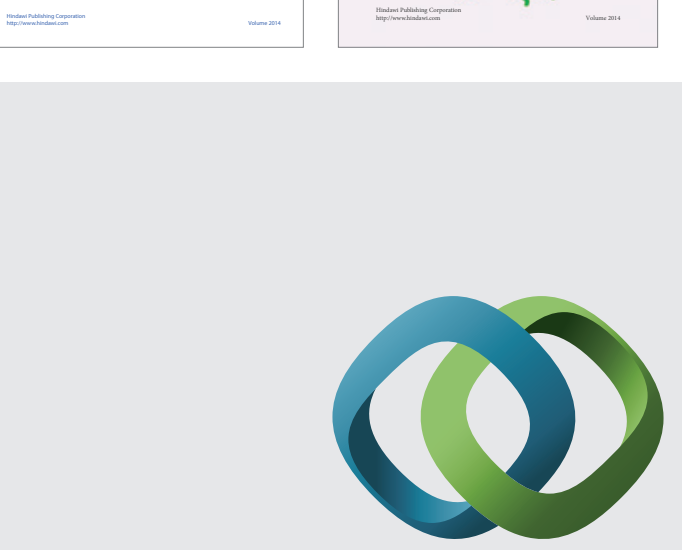

\section{Hindawi}

Submit your manuscripts at

http://www.hindawi.com
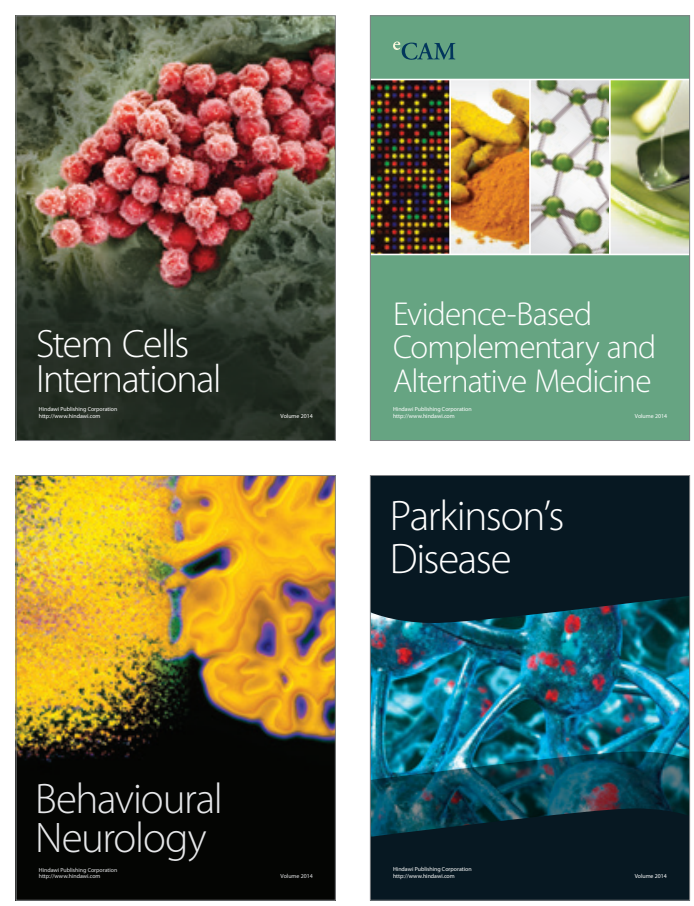

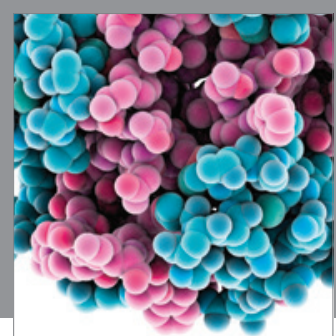

Journal of
Diabetes Research

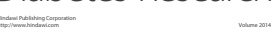

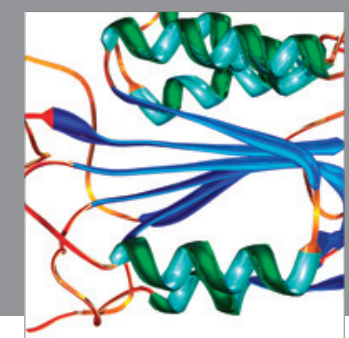

Disease Markers
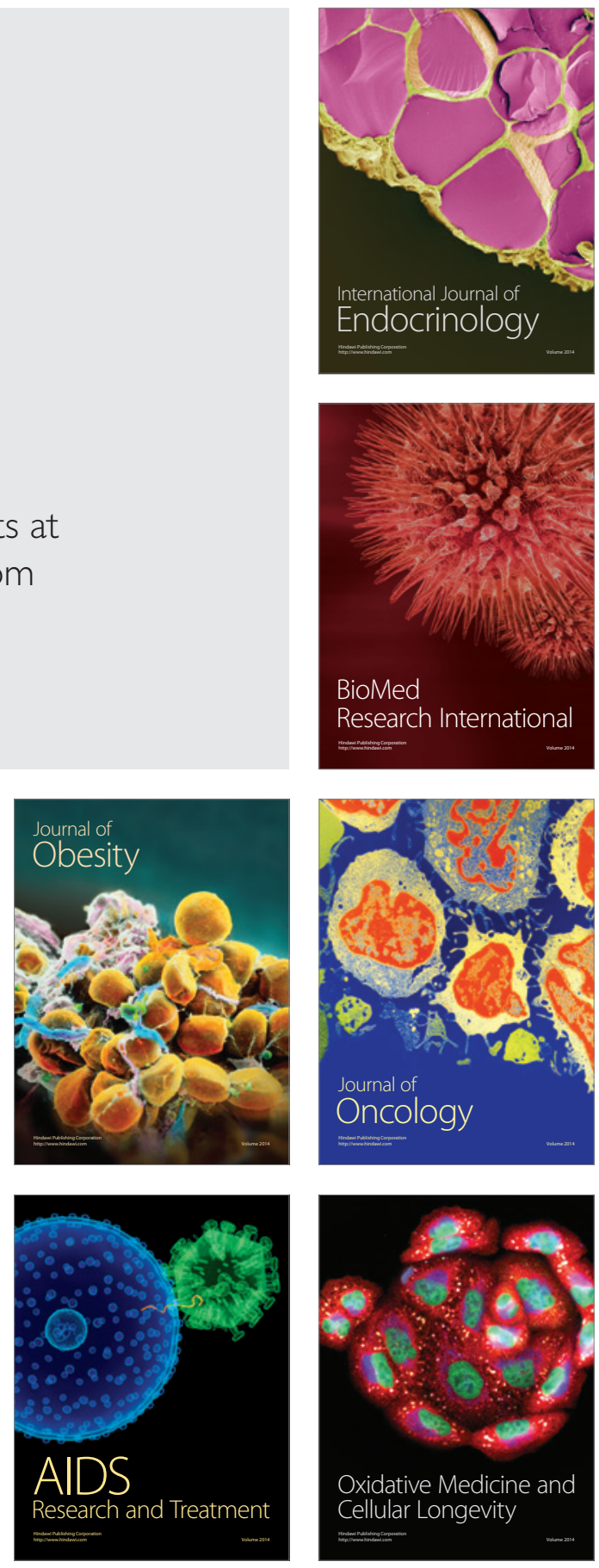